\title{
Sensory Garden Design Solutions in Child Friendly Environments (Case Study: The Children of the City Of Isfahan, North West- District \#12, in Pre-Elementary and Elementary Schools)
}

\author{
Reihane Nikravesh* and Seyedeh Marziah Tabaeian \\ Department of Architecture, Isfahan (Khorasgan) Branch, Islamic Azad University, Isfahan, \\ Iran. \\ *reihannik@gmail.com
}

\begin{abstract}
Different stages of child development indicate that a large amount of children's learning process is gone through by perceptual skills related to the surrounding environment. Besides, children need to be active and stimulate their own senses in the environment more than others. The aim of the present study is to find out the importance of the existence of the environmental stimuli in child friendly spaces. Moreover, this study analyzes the characteristics and patterns of outdoor designs responsive to children's senses, and also deals with the way these outdoor designs affect children's growth. This research is a descriptive-analytic study, and the approach of the research is psychological. This study uses documentary resources to reveal the concepts and the importance of the issue. Finally, the research distributes questionnaires to obtain the characteristics of designing the sensory garden. The findings of the study revealed these design solutions: 1.Appealing and friendly environment, 2.Active participation and the integration of ideas, 3.Access to a variety of activities, 4.The possibility of free games, 5.Natural and green spaces, 6.Individual and group activities, 7.Social interaction, 8.Perception and understanding of values, 9. Different space colors. In this respect, the sensory garden leads to improving the healthy senses and the gradual growth of children's senses.
\end{abstract}

Keywords: Sensory Garden, Children, Child Friendly, Nature, Qualitative and Quantitative Methods.

\section{INTRODUCTION}

A child friendly space is an environment that not only provides the necessary conditions to perform a variety of social activities and interactions for children, but also creates opportunities for children to learn from the environment.

Psychologically speaking, these kinds of environments cause the sense of being useful and effective in children (Mansouri, 2010). Besides, a child friendly environment should be available to all children and should provide suitable grounds for playing, learning, social interaction, and mental and cultural growth (Unicef, 2001). Based on emotional, social and mental resources and feeling at home, appropriate opportunities are given to the children to explore the environment. As a consequence, "child friendly construction" can include a set of meaningful activities that provide the necessary conditions to create a sense of personal and collective belonging for children and adults (Nordstrom, 2010). Two method should be paid attention in order to create child friendly spaces: "creating and designing an environment for children" and "creating and designing the environment with children". Four major principles of security, green nature and space, access, and integrity should be focused in designing a child friendly space for them. On the other hand, participating children in the process of creating the environment can be regarded as the main principle in designing with children. Therefore, one of the major factors of a child friendly space includes the green nature, as the space which the present article deals with. Sensory garden is a kind of natural space which has a variety of aspects including color, texture, etc. and its aim is to be responsive and to stimulate the children's senses (Hussein, 2011). In fact, the idea of designing the sensory garden has been generated in urban environments, especially in child friendly projects due to the therapeutic effects of open and natural spaces on children. Multiple stimuli in a natural 
environment are provided in these kinds of gardens, in order to create different experiments for children. Besides, sensory garden can be used for those with special needs, especially for blind children, and their educational spaces, in which security is a considerable principle (Shoemaker, 2002). Therefore, a sensory garden should be a place which invites the users. In this regard, environmental psychologists refer to the idea of "Biophilia", which means "the sense of liking the nature" by children. They believe that paying attention or not paying attention to this natural sense can have positive and negative psychological consequences in people especially in children (Fjortoft, 2004). Therefore, the therapeutic effects of the nature can affect three aspects of human beings' life, especially that of children's: "physical activities", "mental conditions" and "social skills", and all of these aspects have direct impacts on people's physical and mental health in their daily life (Cooper-Marcus, 1998). The aim of this study is to discover the role of the environmental stimuli on children development in child friendly spaces. Moreover, the present study analyzes the elements of outdoor designs, which are important in the viewpoints of children. This study also tries to offer designing solutions of sensory garden. Therefore both qualitative and quantitative methods are applied and the children's paintings and their teachers' viewpoints are analyzed by using a statistical software. Finally, the related diagram is provided and the related guideline is offered.

\section{SIGNIFICANT PRINCIPLES IN CREATING CHILD FRIENDLY ENVIRONMENTS}

\subsection{Creating and Designing an Environment for Children}

According to the experts, security has a vital role in human being's mental health. In the classification of human beings' needs, Abraham Mazloo introduces comfort feelings (after physiologic needs; food and water, etc.) as the second fundamental needs of human beings, and relates that with social and physical abilities of the environments (Salehi, 2008). Jane Jacobs (1961) believes that one of the factors of creating a secure feeling in the environment is the possibility of monitoring the environment by the users and citizens, which would be a selfdisciplinary environment. One of the main necessities of a child friendly city is to focus on security (Unicef, 2007). Children who feel secure are more likely to engage in outside activities, and are mentally and physically healthy (Carmona, 2003; Spencer \& Woolley, 2000).
The green spaces of children's senses are of

the important issues in child friendly spaces (Unicef, 2005). Children who have direct connections with the nature will have suitable levels of function and cognitive attention and will receive lower levels of stressful conditions and depression (Wells, 2000). Besides, if children repeatedly commune the nature, they are helped to understand the concept of responsibility and respectful interaction with natural environments (Wilson, 2008; Tai et al, 2006; Bott et al, 2003).

Psychologically speaking, factors like economic, social, and cultural status of a community can affect the level of accessibility of children to the public spaces (parks, children's places, etc.). Besides, there is no need for the adults to worry about the safety of the places, when children are using them, and should be free and similar for all the children (Pickett et al, 2001). Therefore, creating the necessary facilities for children to have an easy and desirable access to the public places provides conditions for children to actively participate in the society's activities (Mc Allister, 2008).

Allowing children to participate in decision making processes and to design children's centers is one option, which creates similar opportunities for children to interact socially, increase self-confidence and improve their mental and social health. In fact, considering ideas and beliefs of children and also attempting to integrate children's ideas with the ideas of the community is one of the fundamental requirements in designing child friendly spaces (Unicef, 2007).

\subsection{Creating and designing the environment by children}

Chawla (2002) believes that participating people in social activities cause an increase in people's self-esteem and to be effective in the society. Therefore, it can be inferred that in order for children to gain environmental experiences, they should participate in activities, and change the environment based on their perspectives and requirements (Cele, 2006; Bridjeman, 2004). Roger Hart (1997), one of the outstanding researchers in this domain, has drawn "a ladder of children's participation" which specifies the potential capacity of participation. Hart considers three lowest stairs of the ladder as "lack of participation" and believes that many projects have been performed without the presence of the children. These projects do not belong to the upper stairs 


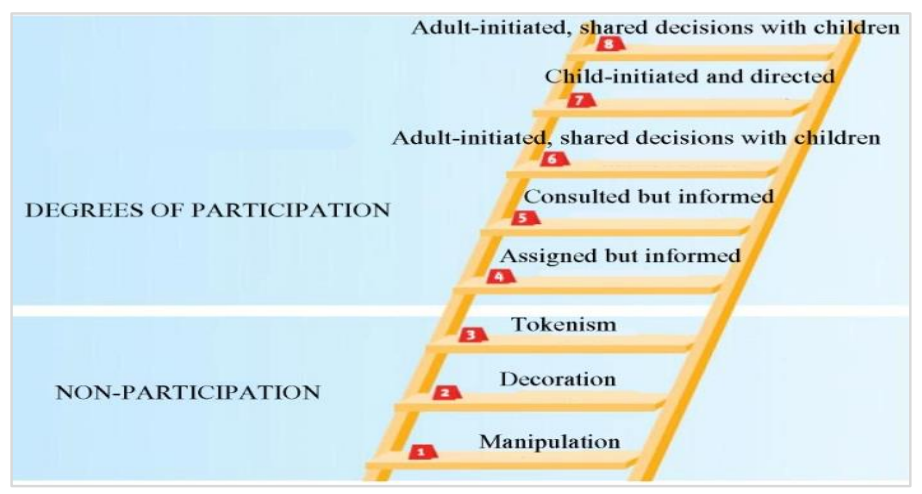

Figure 1: The Ladder of Participating Children (Source: Hart, 1997)

\section{THE ROLE OF NATURE IN CHILDREN'S ENVIRONMENTS}

Since children imagine their surrounding world like a kind of playground, nature is a suitable basis that can amuse them for several hours (Fjortoft, 2004). The reason for this is probably the children's environmental preferences and their inner tendency to the nature. Children can be amused several hours with water, sand, and so on. They can be entertained by running through the trees, and experience lively activities (running, rolling, climbing barriers, etc.) (Zamani, 2009). The type of children's experience in the nature is even totally different from that of adults. In fact, nature in children's view is an occasion for search in the natural environment and earning new experiences. On the contrary, adults consider nature a kind of "background"; they only focus on the aesthetic aspect of the nature (Izad Panah Jahromi, 2004). On the other hand, plant diversity and uneven surfaces of the nature has been appealing for children; also, open spaces activate children's intuitions and their creative power (Fjortoft \& Sajeie, 2000). Moreover, the presence of children in natural environments and gardens, and their attendance in planting and growing plants encourages them to participate in group activities and helps children to improve their body and spirit's health (Sullivan et al, 2004).

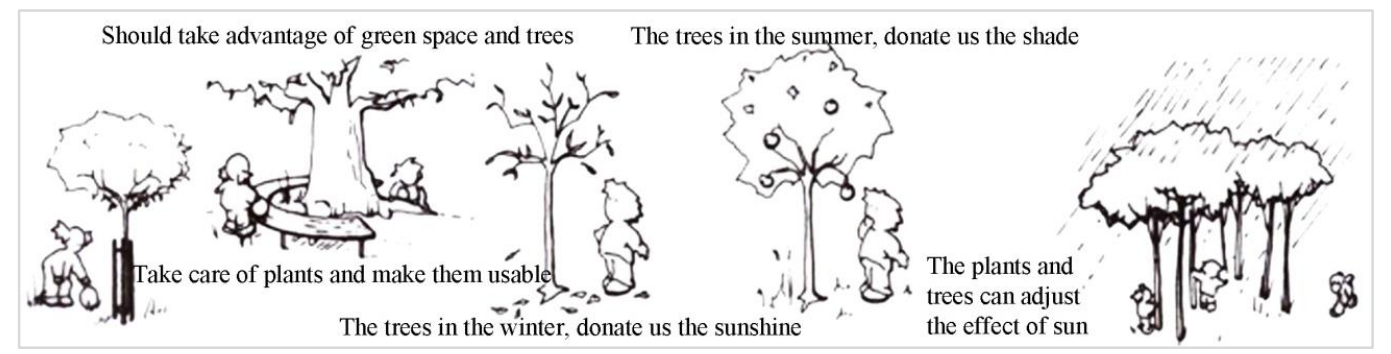

Figure 2: The Importance of nature in children's space (Source: Del Alamo, 2004)

\section{EFFECTS OF CHILD'S SENSES IN UNDERSTANDING THE ENVIRONMENT}

Human being's life experiences are controlled by his feelings. Moreover, all spaces have emotional effect. Based on this fact, the capacity of sensory processing of human being begins since his birth; this sensory processing nurtures during his childhood. In fact, by using their senses, children gain experience from their surrounding environment and before starting to see or speak, they try to differentiate between the inside and outside world (Isbell \& Isbell, 2007). Based on this fact, architects should pay attention to different aspects of human being's senses and their relations with architecture (Table 1). 
Table 1: The Effects of the child's senses on understanding the environment

\begin{tabular}{|c|c|}
\hline Senses & Characteristics of the senses \\
\hline Sight & $\begin{array}{l}\text { - Visual awareness causes the most comprehensive information to be received } \\
\text { from the surroundings. } \\
\text { - It gives us information about the nature of objects. } \\
\text { - It encourages the child to touch the environments' elements and prepare the } \\
\text { condition to face other senses (Day, 2007). } \\
\text { - It is regarded as a navigator factor in the environment. } \\
\text { - It gives us some information about the way the environments' elements affect the } \\
\text { child. } \\
\text { - It is an instrument for inducing memories from the environment. }\end{array}$ \\
\hline Smell & $\begin{array}{l}\text { - Scents are used in order to improve the mood, change people's perspective } \\
\text { regarding the environment and the way of their mental function. On the other } \\
\text { hand, scents reduce the stress, improve the mood and power in children } \\
\text { (Augustin, 2009). } \\
\text { - It gives us information about the objects' nature. }\end{array}$ \\
\hline Hearing & $\begin{array}{l}\text { - Sounds help children to know more about the environment. In fact, hearing } \\
\text { sounds is the same as experiencing in the environment. } \\
\text { - Children enjoy hearing unusual sounds (tunnels, caves, walls that reflect the } \\
\text { sound) because these sounds improve their imaginations. } \\
\text { - Confusing acoustics in spaces decrease the level of the child understanding } \\
\text { (Spencer \& Blades, 2006). } \\
\text { - It gives us information about the way the environments' elements affect the child }\end{array}$ \\
\hline Taste & $\begin{array}{l}\text { - Children taste the objects many times by their tongue; this is a natural response } \\
\text { to understand the environment (Day, 2007). }\end{array}$ \\
\hline Touch & $\begin{array}{l}\text { - It has a significant relation with child's feelings and emotions, and the child's } \\
\text { tendency is to touch objects. } \\
\text { - Children use this sense to communicate with spaces and this sense cause them } \\
\text { understand the environment better. } \\
\text { - It gives us information about the way the environments' elements affect the child } \\
\text { (Day, 2007). }\end{array}$ \\
\hline
\end{tabular}

(Source: Authors, 2015)

Therefore, it can be said that understanding has been a significant factor of human beings' senses; it creates a final continuous sense. Finally, paying attention to children's senses helps them to explore their surrounding environment. Accordingly, spaces can create feelings in people, make memories and increase their

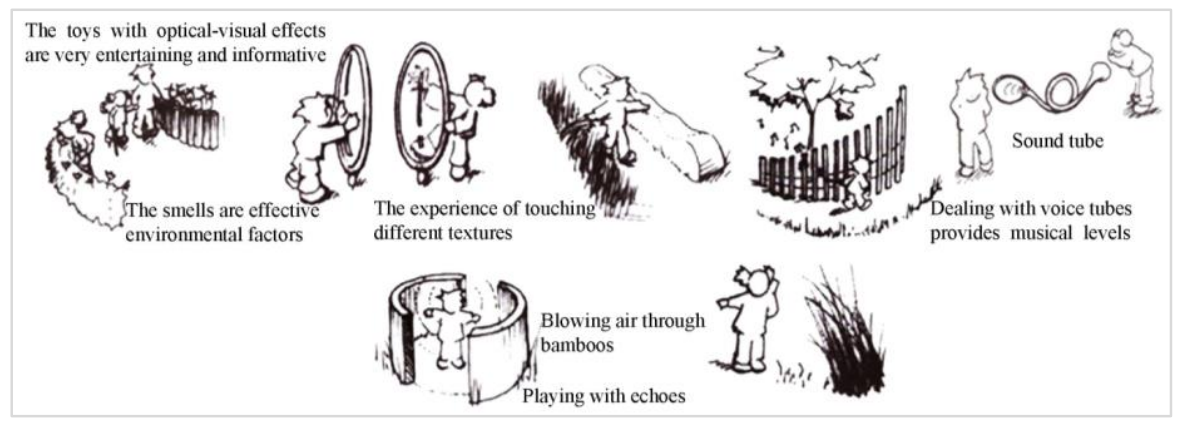

Figure 3: The Importance of motivating children's senses in the playground

(Source: Del Alamo, 2004) 


\section{THE ROLE OF PATTERNS AND TEXTURES IN THE SENSORY GARDEN}

Using patterns and textures in children's environments not only stimulates sight and touch senses, but also affects them psychologically. On the other hand, these kinds of architectural details either stimulate children or bore them. Therefore, an environment with different and suitable patterns can increase child's mental activities and play a role in growing the child's imagination and creativity (Day, 2007). On the other hand, using too many visual patterns can prevent children to concentrate, leading them to confused feelings. However, psychologically speaking, the environments, which did not use any patterns or textures are not suitable for the users. Therefore, it can be said that the appropriate and correct use of patterns can be effective in increasing productivity of the environment (Mahnk, 1996). Thus, applying patterns and textures in children's environments is the main part of designing the buildings and decorations, which cause the environment to be surprising and attracting. Also, it is worthy to refer to some psychological effects of the patterns, as follows:

- Using messed up patterns in small environments leads to stress and anxiety.

- Direct horizontal lines makes one feel relaxed; however, using too many lines leads to tense feeling among children.

- Direct vertical lines show the state of stability; and diagonal lines indicate activity.

- Forms which are the same as V indicate danger and cause attention.

- Using rhythm in children's spaces, considering the way of repeating the elements with their gradual change is a sight guiding factor in the spaces.

- The created patterns by flagstones demonstrate the route and the sight distance; these patterns cause the feeling of movement.

- Using patterns in walls and ceilings cause a feeling of protrusions or retreat (Mahnk, 1996).

\section{THE IMPORTANCE OF ENVIRONMENTAL GRAPHICS IN SENSORY GARDEN}

Environmental graphic in children's spaces is the wise use of visual factors in the environment in order to create a desirable environment for the user and to demonstrate the appropriate behavior and reaction (Ilookhani, 2009). In fact, the main duty of environmental graphic is to be aware of the aesthetic growth of the child, to understand the methods of education and to transfer concepts to him through the environment. Generally speaking, children's educational methods are divided to two groups of direct education (education at school) and indirect education. Therefore, environmental graphic can play a significant role in growth of characteristics and mental growth of children by child indirect training, and can stimulate curiosity and creativity of the child, and enrich the environment (Aramfard, 2001). In fact, the appropriate use of environmental graphic helps the child's senses get involved, curiosity is reinforced, and the child be trained by playing in the environment. Some samples of environmental graphic in children's space are addressed, as follows:

- Designing graphic volumes in the forms of plants and flowers; with different flowers' scents, not only the smell sense is motivated, but also the children's curiosity is satisfied.

- Designing volumes which provide the possibility to hear pristine sounds of the nature for children.

- Applying wind power to swing different aquatic, animals and birds over a rod is significant to make the child feel that something is moving.

- The combination of alphabets related to the animal statue is effective in learning and training children.

- Lighting the environment and children's open spaces by luminous volumes of animals and insects improves the child's relationship with other entities and provides the environment's security in the darkness.

- Designing furniture of children's open spaces in the form of petals of the flowers aims at teaching shapes and counting the numbers. Moreover, children can change the form of mobile furniture to increase the sense of partnership and responsibility (Del Alamo, 2004). 

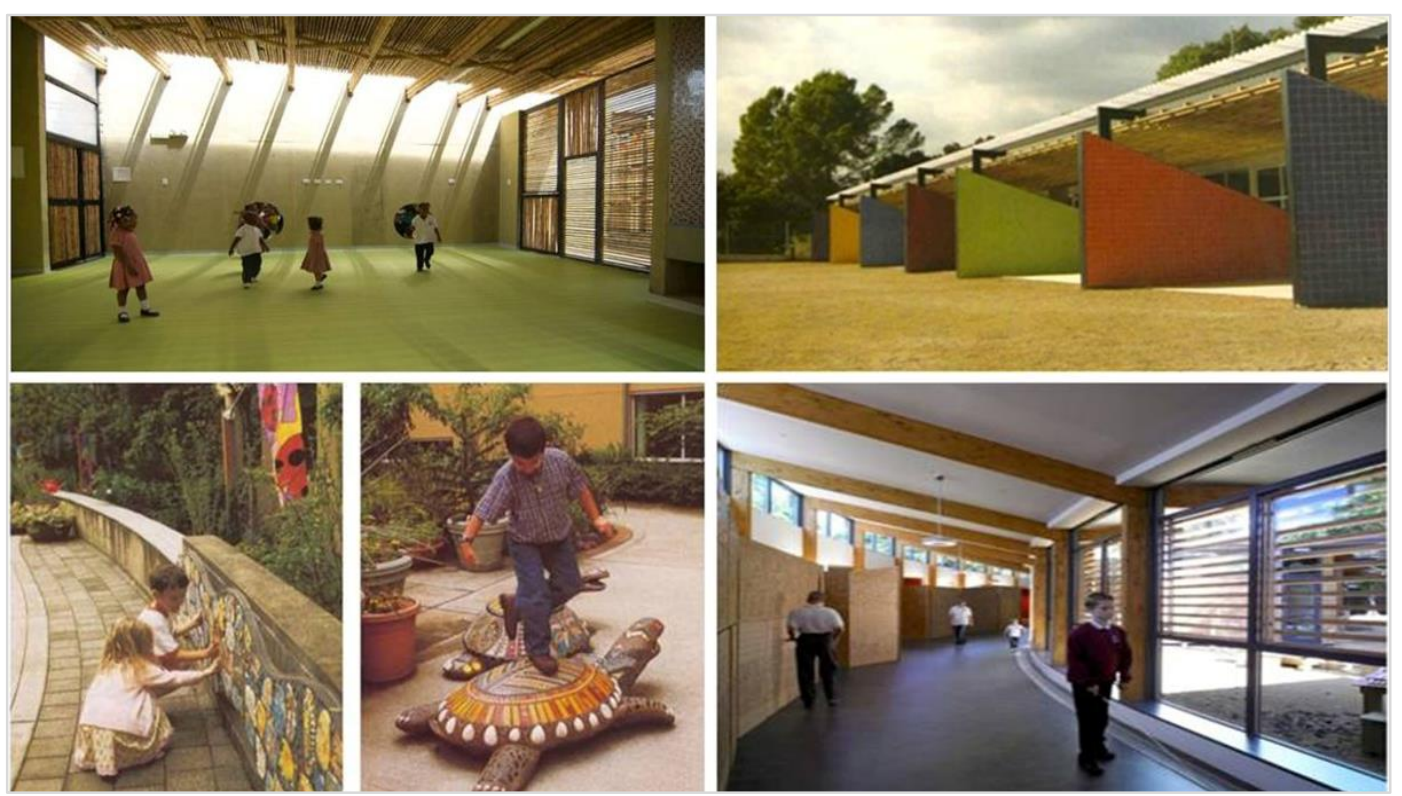

Figure 4: Samples of design patterns and textures on the children's spaces (Source: Tabaeian et al., 2015)

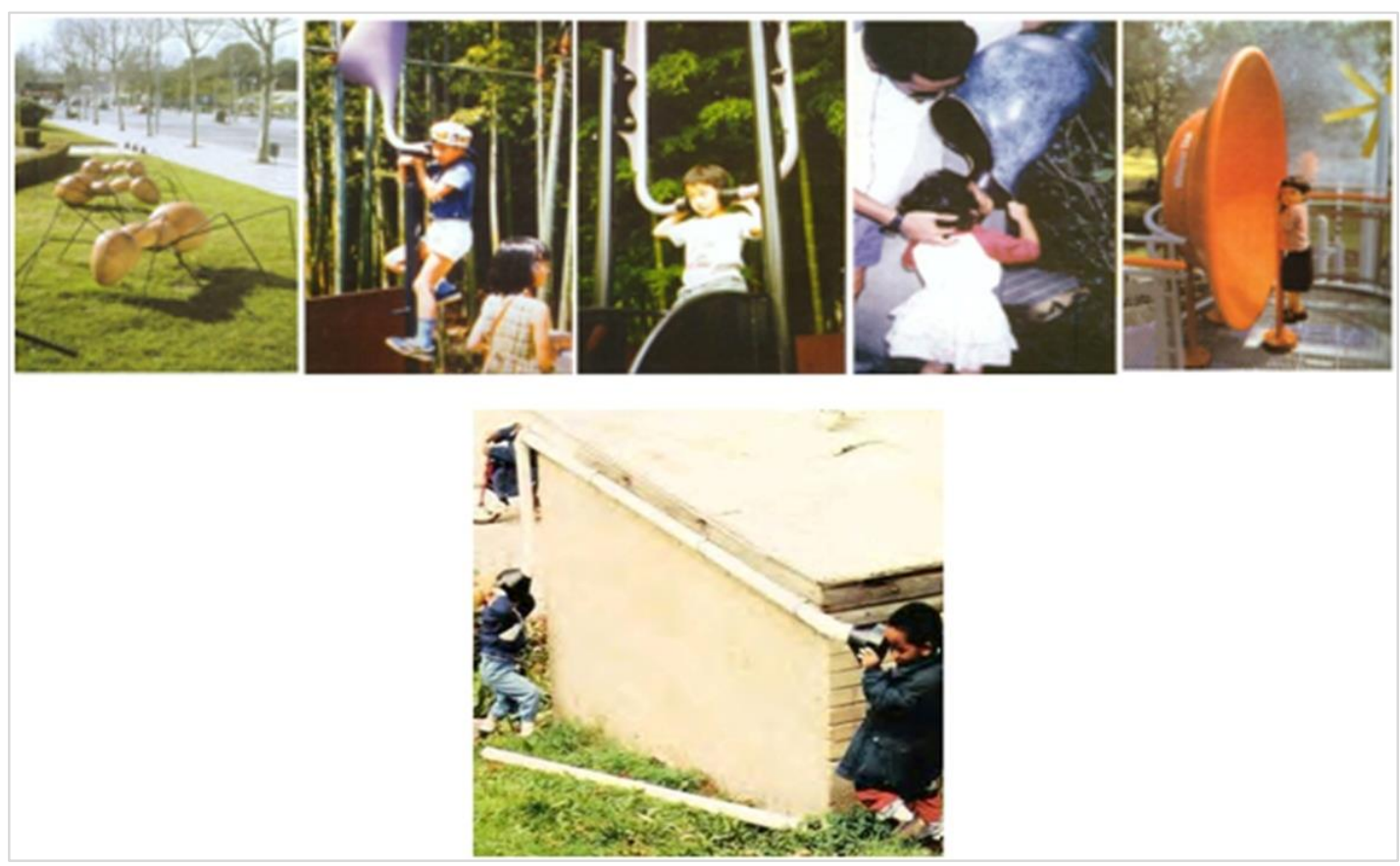

Figure 5: Samples of environmental graphic in children's space (Source: Satari \& Eghbali, 2014) 


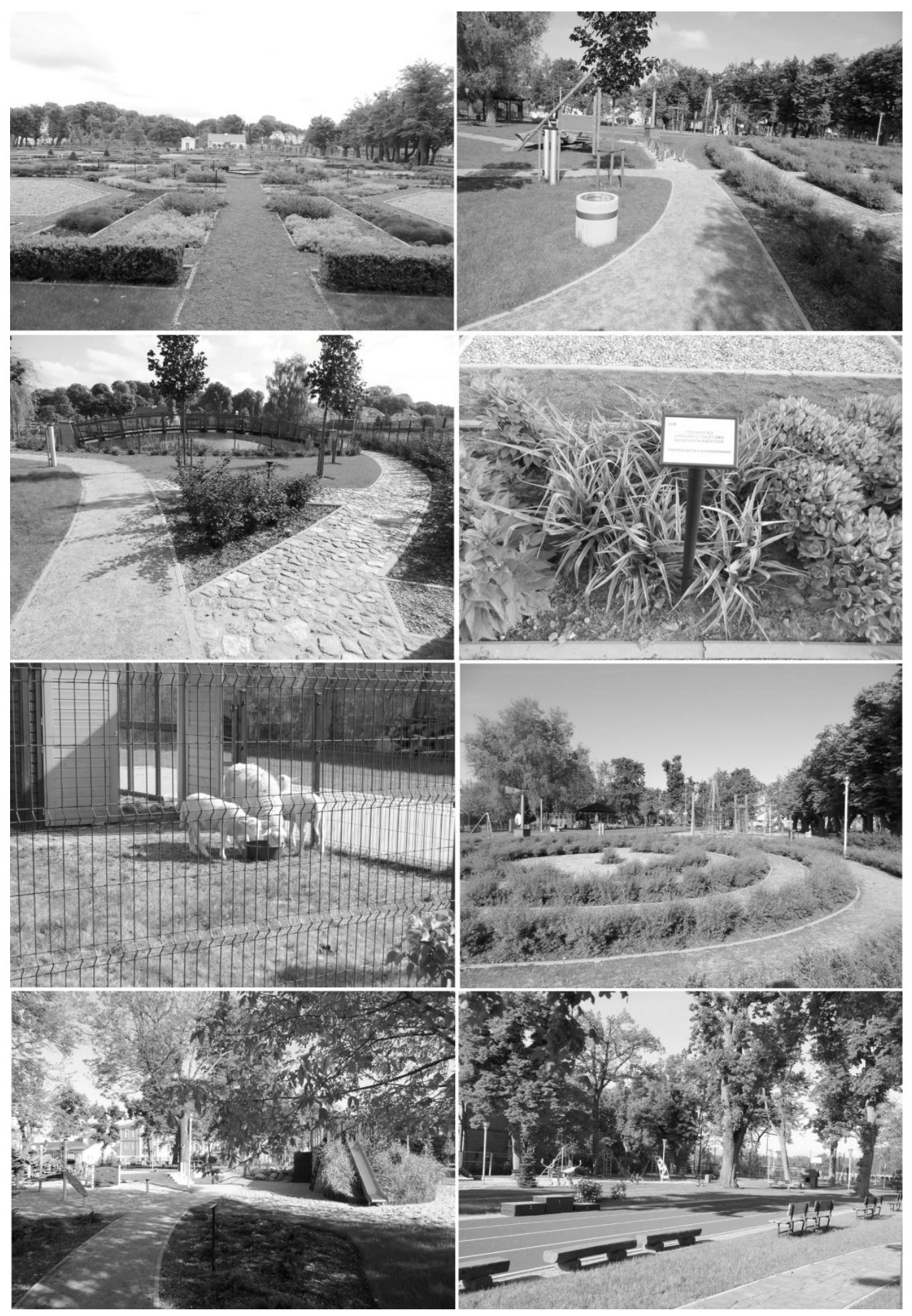

Figure 6: A Sample of the sensory garden's details of Owinska's Park (Source: Hussein, 2011) characteristics: (1) contains different textures, sounds and smells, (2) contains spaces for playing which have different barriers for children to facilitate navigating their way, (3) preparing some routes with different levels which leads to the lake and bridge, (4) sings which are written with Braille to provide some explanations about the plants, (5) containing sports facilities, (6) containing animals' farm 


\section{METHODOLOGY}

In this research, qualitative and quantitative methods are both applied; and collecting data is through library resources. It should be mentioned that considering its method of collecting quantitative data, the present study is placed among the cross-sectional studies. Moreover, since qualitative data, especially children's paintings, are representative of children's thoughts, behaviors and feelings, the author attempts to interpret and code the desirable behaviors of children; therefore, the qualitative-phenomenology aspect of the study is also significant. The study population contains Isfahan city's educational centers (preelementary and elementary schools) and the sample of the study (purposive sampling procedures) is chosen as the children of Isfahan city's Education organization/ northwest district $\# 12$, and their teachers and trainers are also chosen. Therefore, the field studies were performed in pre-elementary and elementary schools that exist in this district. Parande Koochak pre-elementary school, Ghobe elementary school (girls' school) and Shahid Golshirazi elementary school (boys' school) were selected to carry out the study. The sample population (purposive sampling procedures) contains 115 children and 25 teachers and trainers. Moreover, choosing teachers and trainers of this group has also been a purposive sampling since the purpose is to have the same environmental conditions for the child and the teacher (as an expert). Furthermore, it is aimed for the child and the teacher to have interaction with each other. In the present study, the questionnaires are analyzed by using the statistical software (SPSS, X2) and (T-student) test. Also, the software (Atlas.Ti6.2) is applied in order to analyze the children's paintings. Finally, the obtained frequencies are transmitted to Excel software and the related diagram is thus provided.

\section{DATA ANALYSIS AND FINDINGS}

In the present study, first two effective components on child friendly spaces are analyzed by using the trainers' ideas. These two components are: "appealing and friendly environment" and "participation of active children". Then, the research analyzes the children's ideas in relation to their level of interest, regarding their presence in natural spaces and sensory garden, and then the effects when children are present in natural spaces.

Question 1. The school's environment (or the nursery school) is friendly and inviting. How friendly and inviting is your school or nursery school? School (or nursery school) is considered as an appealing place for the students (or children) and the employees. How appealing is your school (or nursery school)? How appealing and friendly is the sample?

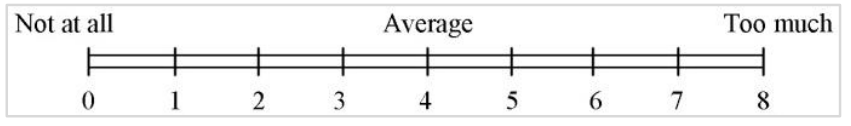

Table 2: The average of the appealing and the friendly environment's variable

\begin{tabular}{|c|c|c|c|}
\hline & The sample & The average & Standard Deviation \\
\hline $\begin{array}{c}\text { Appealing and Friendly } \\
\text { Environment }\end{array}$ & 25 & 5.08 & 1.63 \\
\hline
\end{tabular}

(Source: Authors, 2015)

Table 3: The results of T-test regarding the comparison between the appealing and friendly environment and the average

\begin{tabular}{|c|c|c|c|}
\hline The variable & $\mathrm{t}$ & Degree of Freedom & The Meaningful Amount \\
\hline Appealing and Friendly Environment & 3.25 & 23 & 0.004 \\
\hline
\end{tabular}

(Source: Authors, 2015)

The amount of t-test for the friendly and appealing environment average is 3.25 and the amount of the possibility related to the analysis of its being meaningful is 0.004 that is less than 0.05 . Therefore, $95 \%$ certainty of the statistical zero based on the equality of the appealing and friendly average with the average amount is dismissed. Therefore, the average rate of the friendly and appealing environment with the average is " 4 " and higher amount than 4 of the 
average amount of the appealing and friendly environment is meaningful, therefore, it can be said that the friendly and appealing environment's average is high.

Question 2. There is a written program at school (or nursery school) in order for the children to participate in educational programs. How similar is your school (or nursery school)?
There is a possibility for student (or children) to freely and openly express their feelings and thoughts regarding the activities and environment of the school (or the nursery school). How much is your school (or your nursery school) similar to the above conditions? How much is the children's active participation in the sample?

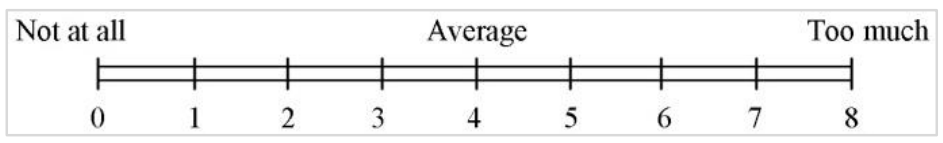

Table 4: The Average of the active participation variable and the integrated opinions

\begin{tabular}{|c|c|c|c|}
\hline & The sample & The Average & The Standard Deviation \\
\hline $\begin{array}{c}\text { Active Participation and the } \\
\text { Integration of ideas }\end{array}$ & 25 & 4.81 & 1.78 \\
\hline
\end{tabular}

(Source: Authors, 2015)

Table 5: The Results of t-test regarding the comparison between the active participation \& the ideas' integration with the average amount

\begin{tabular}{|c|c|c|c|}
\hline The Variable & $\mathrm{t}$ & $\begin{array}{c}\text { Freedom } \\
\text { Degree }\end{array}$ & $\begin{array}{c}\text { The Meaningful } \\
\text { Amount }\end{array}$ \\
\hline $\begin{array}{c}\text { Active participation \& the integration } \\
\text { of ideas }\end{array}$ & 2.23 & 23 & 0.036 \\
\hline
\end{tabular}

(Source: Authors, 2015)

The amount of t-test of the active participation average and the integration of ideas is 2.23 and the amount of the possibility related to its meaningful analysis is 0.036 which is less than 0.05 . Therefore, $95 \%$ certainty of the statistical zero based on the equality of the active participation average with the integration of the ideas is dismissed. Therefore, because the average of the active participation and the integrity of ideas with the average and higher amount of 4 of the average amount of the active participation and the integration of ideas are meaningful, therefore, it can be said that the average of the active participation and the integration of ideas are in a high level.

Table 6: The final results of teachers' opinions regarding the sample in question

\begin{tabular}{|l|c|}
\hline \multicolumn{1}{|c|}{ Components } & $\begin{array}{c}\text { The amount of Analyzed } \\
\text { Data by T-student Test }\end{array}$ \\
\hline The Level of the Child Friendly Environment & in a High Level \\
\hline Active participation and Paying Attention to the Children's Ideas & in a High Level \\
\hline
\end{tabular}

(Source: Authors, 2015)

According to the results of various researches, paying attention to the purposeful design of the open and green spaces of the children's center is one of the priorities of the design. Based on this, it is assumed that the children by prioritize green and natural spaces. This theory is proved to be based on the following findings: 


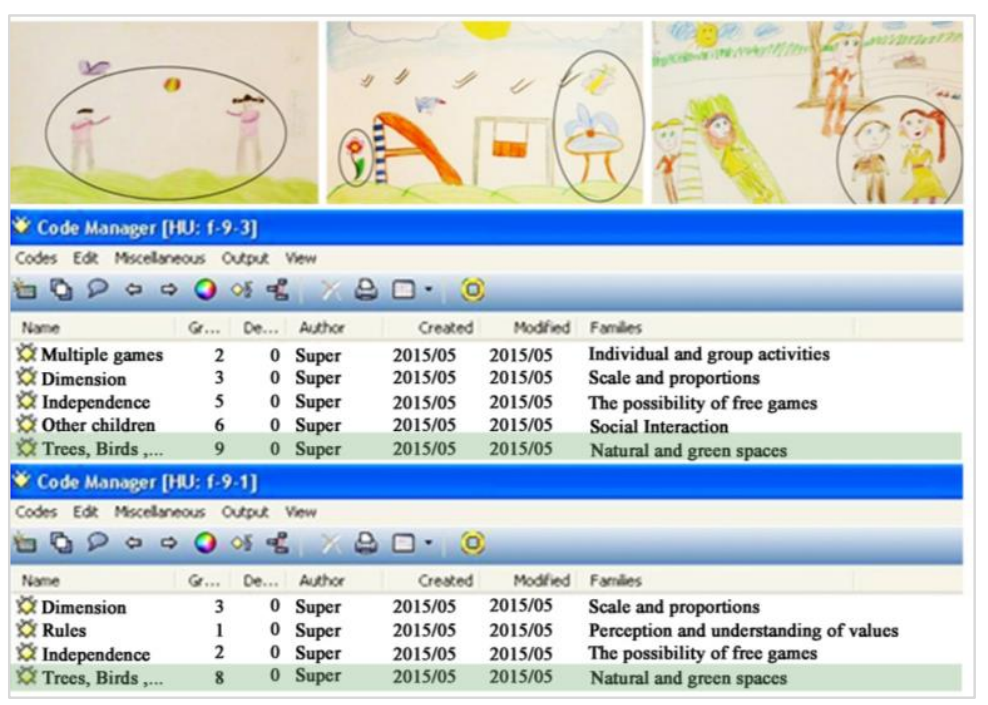

Figure 7: A Sample of children's paintings \& the process of its analysis by the software" Atlas.Ti 6.2" (Source: Authors, 2015) Point: The obtained frequencies in each table is the results of analyzing 10 paintings.

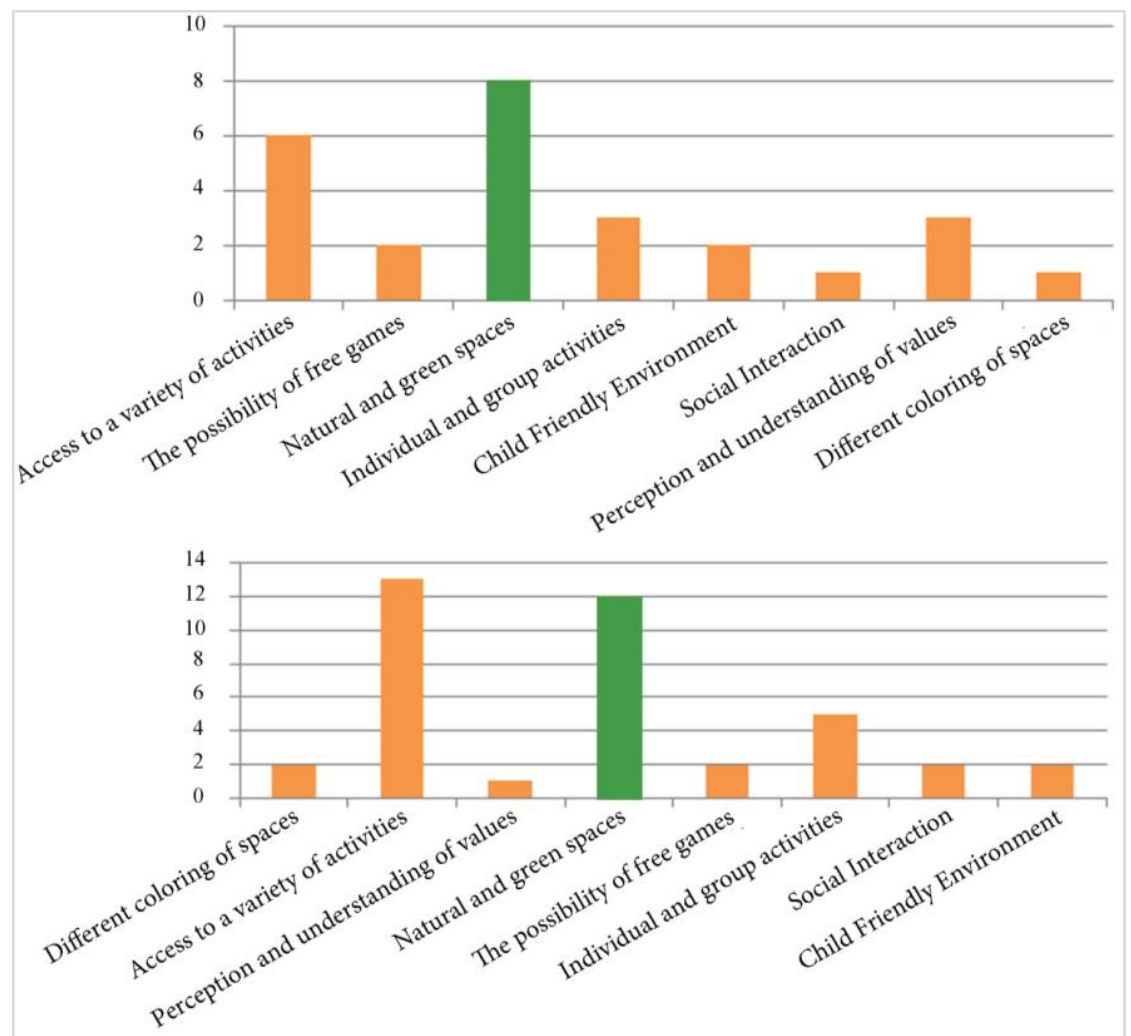

Figure 8: (above) Male children's ideas' assessment;

(below) Female children's ideas' assessment

(Source: Authors, 2015)

Based on the findings of different researches, it can be said that both groups of girls and boys have natural tendency towards the nature and green spaces; they prefer their open space integrate with their natural spaces. Based on the above diagrams, the green space is the first priority or the second priority of children's choice and this fact reminds us of the importance of paying attention to the landscape design and the children's educational gardens, especially sense garden. 


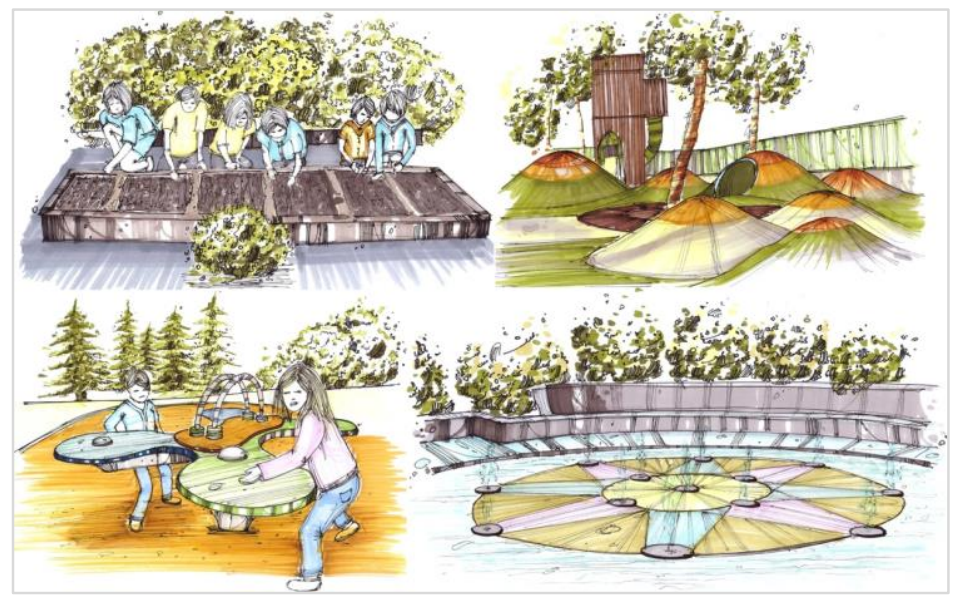

Figure 9: Suggestions for designing different spaces of sense garden (Source: Authors, 2015) Characteristics: (1) Creating solitude spaces in the hill surfaces of sense garden can increase the sense of research among children, (2) Creating some opportunities for planting flowers and plants for children leads to stimulating children's sense of liking the nature and their participation and also their senses of smell, touch, etc. , (3) Situating lakes and fountains in children's sense garden which leads to creating a marked place and also stimulating children 's sense of hearing, (4) Embedding apparatuses which cause playing the sounds and can stimulate children's hearing sense.

Table 7: Analysis of the findings

\begin{tabular}{|c|c|c|c|}
\hline $\begin{array}{l}\text { The obtained } \\
\text { components from library } \\
\text { studies }\end{array}$ & $\begin{array}{l}\text { The positive points of } \\
\text { field observations for } \\
\text { samples }\end{array}$ & $\begin{array}{l}\text { Proposed elements in the } \\
\text { paintings of children and } \\
\text { teacher's interviews }\end{array}$ & Design solutions \\
\hline $\begin{array}{l}\text { Appealing and friendly } \\
\text { environment }\end{array}$ & $\begin{array}{l}\text { *Using childish characters } \\
\text { on the facade } \\
* \text { Childish frescoes in the } \\
\text { connection spaces }\end{array}$ & $\begin{array}{l}\text { *Refers to the pond of } \\
\text { paintings (water colors on } \\
\text { the floor, etc) } \\
\text { *Refers to the stairways } \\
\text { (as an attractive element } \\
\text { for children) } \\
\text { * Refers to the pool of ball } \\
\text { (as a charming and } \\
\text { colorful element for } \\
\text { minors) } \\
\text { *The presence of hills in } \\
\text { the playgrounds }\end{array}$ & $\begin{array}{l}\text { *Pay attention to childish } \\
\text { and decorative elements in } \\
\text { the interior and exterior } \\
\text { spaces } \\
\text { *Create quiet game's zone } \\
\text { (playing with sand, water, } \\
\text { etc.) } \\
\text { *Create visual game's } \\
\text { zone (considering the } \\
\text { walls and floors in the } \\
\text { playground which can be } \\
\text { used for painting) } \\
\text { *Create stairways and hills } \\
\text { in the playground }\end{array}$ \\
\hline $\begin{array}{l}\text { Active participation and } \\
\text { the integration of ideas }\end{array}$ & - & - & $\begin{array}{l}\text { * Create flexible spaces in } \\
\text { children's centers and } \\
\text { provide the possibility of } \\
\text { changing and shaping the } \\
\text { environment by children }\end{array}$ \\
\hline $\begin{array}{l}\text { Access to a variety of } \\
\text { activities }\end{array}$ & $\begin{array}{l}\text { *Pay attention to the } \\
\text { variety of games based on } \\
\text { age groups }\end{array}$ & $\begin{array}{l}\text { *Refers to various play } \\
\text { equipment (swings, slides, } \\
\text { etc.) } \\
\text { *Refers to various games } \\
\text { in Painting and interviews } \\
\text { (jumping rope, etc.) }\end{array}$ & $\begin{array}{l}\text { *Create different play } \\
\text { zones with regard to } \\
\text { overall growth needs of } \\
\text { children } \\
\text { *Providing facilities and } \\
\text { playing instruments } \\
\text { suitable for children }\end{array}$ \\
\hline $\begin{array}{l}\text { The possibility of free } \\
\text { games }\end{array}$ & $\begin{array}{l}\text { *Presence of children with } \\
\text { indirect supervision of } \\
\text { coach }\end{array}$ & $\begin{array}{l}\text { *The presence of children } \\
\text { for free, either alone or } \\
\text { together with other } \\
\text { children in the playground }\end{array}$ & $\begin{array}{l}\text { *Considering the curators } \\
\text { for each zone and thus no } \\
\text { restriction of parents for } \\
\text { children to play games } \\
\text { *Taking into account an }\end{array}$ \\
\hline
\end{tabular}




\begin{tabular}{|c|c|c|c|}
\hline & & & $\begin{array}{l}\text { entrance for the center and } \\
\text { create fences around the } \\
\text { area to monitor the entry } \\
\text { and exit of children }\end{array}$ \\
\hline Natural and green spaces & $\begin{array}{l}\text { *Enjoy green space } \\
* \text { Create Space of sand- } \\
\text { play (organic) }\end{array}$ & $\begin{array}{l}\text { *Consideration of children } \\
\text { to lawns, trees, flowers, } \\
\text { animals, etc., in paintings }\end{array}$ & $\begin{array}{l}\text { *The presence of harmless } \\
\text { animals in the playground } \\
\text { (turtles, rabbits, etc.) } \\
\text { *The establishment of } \\
\text { various open spaces } \\
\text { (courtyards, patios, etc.) } \\
\text { *The use of various plant } \\
\text { species with different } \\
\text { colors and shapes, } \\
\text { fountain, etc. } \\
\text { *Create opportunities for } \\
\text { gardening and planting } \\
\text { plants in the playground }\end{array}$ \\
\hline $\begin{array}{l}\text { Individual and group } \\
\text { activities }\end{array}$ & $\begin{array}{ll}* \text { Create tables } & \text { and } \\
\text { furnishings in groups } \\
\text { (layout as circular) }\end{array}$ & $\begin{array}{l}\text { *Painting by the children } \\
\text { around a table (group } \\
\text { activities) } \\
\text { *Refers to private spaces } \\
\text { (individual activity) }\end{array}$ & $\begin{array}{l}\text { *Consider to Group games } \\
* \text { Create a room and } \\
\text { furniture for discussion } \\
\text { and storytelling. } \\
\text { *Create individual spaces } \text { in playground } \\
\text { *Create individual } \\
\text { activities (biking, reading, } \\
\text { etc) }\end{array}$ \\
\hline Social interaction & $\begin{array}{l}\text { *Consideration of theater } \\
* \text { The availability of } \\
\text { different services for } \\
\text { children to play exhibition } \\
\text { games with each other }\end{array}$ & $\begin{array}{l}\text { *Painting with friends and } \\
\text { playing with other children }\end{array}$ & $\begin{array}{l}\text { *Consideration of sport } \\
\text { games (to gather the } \\
\text { children together) } \\
\text { *Create social games } \\
\text { (such as theater and } \\
\text { display) to develop social } \\
\text { skills }\end{array}$ \\
\hline $\begin{array}{l}\text { Perception and } \\
\text { understanding of values }\end{array}$ & $\begin{array}{l}\text { *Providing traffic signs } \\
\text { and } \\
\text { (introducing a social value } \\
\text { to children) }\end{array}$ & $\begin{array}{l}* \text { Children refer to the } \\
\text { traffic lights, the Iranian } \\
\text { flag, etc. in their paintings } \\
\text { (perceived social, national } \\
\text { and religious values) }\end{array}$ & $\begin{array}{l}\text { *Use childish elements in } \\
\text { the playground to } \\
\text { introduce different values } \\
\text { to children } \\
\text { *Organize the simple } \\
\text { spaces (avoid designing } \\
\text { complex spaces) to } \\
\text { facilitate children's spatial } \\
\text { perception }\end{array}$ \\
\hline $\begin{array}{l}\text { Different coloring of } \\
\text { spaces }\end{array}$ & $\begin{array}{l}\text { *Use bright colors on the } \\
\text { facade } \\
\text { *Consider to a variety } \\
\text { coloring of spaces }\end{array}$ & $\begin{array}{l}\text { *Indicates a rainbow and } \\
\text { colorful elements in the } \\
\text { painting (the children's } \\
\text { interest in various color } \\
\text { spaces) }\end{array}$ & $\begin{array}{l}\text { *Use favorite colors for } \\
\text { different age groups in the } \\
\text { playground, playing } \\
\text { instruments, interior and } \\
\text { exterior spaces } \\
\text { * Use colored glass frames }\end{array}$ \\
\hline
\end{tabular}

(Source: Authors, 2015)

\section{CONCLUSION}

Designing sense garden involves a variety of aspects, which needs designers' attention. In fact, many designing solutions should be applied to provide multiple sense experiences for the users. Based on the existing evidence, all studies should be carried out based on the sense garden's therapeutic effects which is the most important characteristic of these kinds of spaces and deals with the importance of children's relationship with the nature. 
Table 8: The Final Results of Research

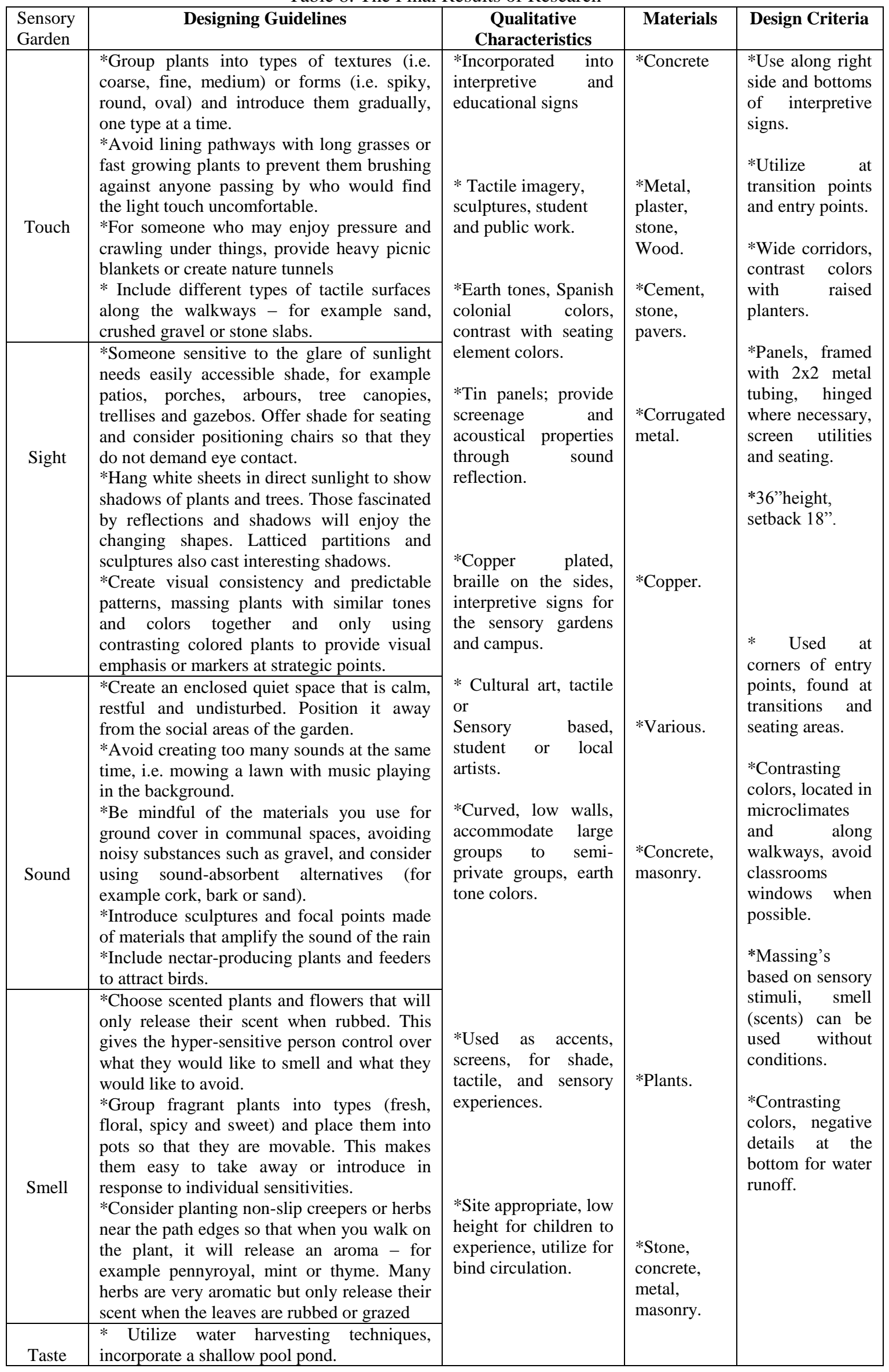




\section{ACKNOWLEDGEMENT}

The author wish to thanks the generous efforts of outstanding professor, Dr. Sayedeh Marzieh Tabaeian and also Isfahan municipality.

\section{REFERENCES}

Aramfard, M. (2001), The Methods of Developing Creativity, The Journal of Movafaghiat, 4(42): 24-35.

Augustin, S. (2009), Place Advantage: Applied Psychology for Interior Design, John Wiley \& Sons, New Jersey.

Bott, S., J.G. Cantrill \& O.E. Myres J.R. (2003), Place and the Promise of Conservation Psychology, Human Ecology Review, 10(2): 100-112.

Bridgeman, R. (2004), Child-Friendly Cities: Canadian Perspectives, Children, Youth and Environments, 14(2): 178200.

Carmona, C., Heath, T., Oc, T. \& Ttiesdell S. (2003), Public Places, Urban Spaces, Architectural Press, New York.

Cele, S. (2006), Communicating Place: Methods for Understanding Children's Experience of Place, Studies in Human Geography, Stockholm.

Chawla, L. (2002), Growing Up in an Urbanizing World, Unesco Publishing.

Cooper-Marcus C., Francis C. (1998), People places, Design Guidelines for Urban Open Space, John Wiley \& Sons, New York.

Day, C. (2007), Environment and Children Passive Lessons from the Everyday Environment, Elsevier Press, USA.

Del Alamo, M.R. (2004), Design For Fun: Playgrounds, Links International, Spain.

Fjortoft, I. (2004), Landscape as Playscape: The Effects of Natural Environments on Children's Play and Motor

(Source: Authors, 2015)
Development, Children, Youth and Environments, 14 (2): 21-44.

Fjortoft, I. \& Sageie, J. (2000), The Natural Environment as a Playground for Children, Landscape and Urban Planning, 48(1): 83-97.

Hart, R. (1997), Children's Participation: The Theory and Practice of Involving Young Citizens in Community Development and Environmental Care, Unicef, New York.

Hussein, H. (2011), The influence of sensory gardens on the behaviour of children with special educational needs, Asian Journal of Environment-Behaviour Studies 2(4): 343-354.

Ilookahni, M. (2009), The Environmental Graphic, Fatemi Publications, Tehran, Iran.

Isbell, C. \& Isbell, R. (2007), Sensory Integration: A Guide for Preschool Teachers, Gryphon House, Beltsville.

Izad Panah Jahromi, A. (2004), Child, Play and City-Process, Planning Principles and Criteria and Designing Open Spaces, The Publications of the Municipalities of the Country, Tehran, Iran.

Jacobs, J. (1961), Life and Death of the Great American Cities, Random House, New York.

Mahnke, F.H. (1996), Color, Environment \& Human Response, Van Nostrand Reinhold, New York.

Mansouri, S.A. (2010), What is the City's Perspective (The Historical Analysis of the Conceptual Developments of the Urban Landscapes in Iran), Monthly Magazine of Manzar, 2(9): 30-33.

McAllister, C. (2008), Child Friendly Cities and Land Use Planning: Implications for Children's Health, Environments Journal, 35(3): 45-61.

Nordstrom, M. (2010), Children's Views on Child-Friendly Environments in Different Geographical, Cultural and Social Neighbourhoods, Urban Studies, 47 (3): 514-528.

Pickett, S.T.A, Cadenasso, M.L., Grove, J.M., Nilon, C.H., Pouyat, R.V., Zipperer, 
W.C. \& Costanza, R. (2001), Urban Ecological Systems: Linking Terrestrial Ecological, Physical and Socioeconomic Components of Metropolitan Areas, Annual Review of Ecology and Systematics, 10(32): 127157.

Salehi, E. (2008), The Environmental Characteristics of the Safe Urban Spaces, The Research and Architecture Center, Iran.

Satari, S. \& Eghbali, P. (2014), The Role of the Environmental Graphic in Educational-Recreational Space of Children's Park, The book Mah Honar, 15(189): 38-45.

Shoemaker, C.A. (2002), Interaction by Design: Bringing people and plants together for health and well-being, An international symposium, Iowa State Press, Ames.

Spencer, C and Blades, M. 2006. Children and their Environments - Learning, Using and Designing Spaces. United Kingdom: Cambridge University Press.

Spencer, C. \& Woolley, H. (2000), Children and the City: A Summery of Recent Environmental Psychology Research, Child care, Health and Development, 26(3): 98-181.

Sullivan, W.C., Kuo F.E., Depooter, S.F. (2004), The Fruit of Urban Nature, Vital Neighbourhood Spaces, Environment and Behavior, 36(5):678700 .
Tabaeian, S.M., Nikravesh, R. \& Abdoli, Sh. (2015), Architecture of educational facilities for children with special needs, Isfahan (Khorasgan) Branch of Islamic Azad University, Iran.

Tai, L., Haque, M.T., Mclallan, G.K., \& Knight, E.J. (2006), Designing Outdoor Environments for Children: Landscaping Schoolyards, Gardens and Playgrounds, McGraw-Hill, USA.

Unicef, (2001), Partnerships to Creat child Friendly Cities: Programming for Child Rights with Local Authorities, Unicef/IULA, New York.

Unicef, (2005), Cities With Children, Child Friendly Cities In Italy, Unicef/IULA, New York.

Unicef, (2007), Child Friendly Cities, Unicef/IULA, New York.

Wells, N.M. (2000), At Home With Nature: Effects of Greenness on Children's Cognitive Functioning, Environment and Behavior, 32(6): 775-795.

Wilson, R. (2008), Nature and Young Children - Encouraging Creative Play and Learning in Natural Environments, Routledge, New York.

Zamani, Z. (2009), Child, Nature, City, The Necessity of Returning Natural Landscapes to the Environment of Children's Life, Manzar Journal, 1(4): 58-61 